\title{
Influence of Ferric and Ferrous Iron on Chemical and Bacterial Leaching of Copper Flotation Concentrates
}

\author{
Ali Ahmadi \\ Department of Mining Engineering, Isfahan University of Technology, Isfahan, Iran \\ Email: a.ahmadi@cc.iut.ac.ir
}

Received July 16, 2012; revised August 26, 2012; accepted September 23, 2012

\begin{abstract}
The effects of ferrous and ferric iron as well as redox potential on copper and iron extraction from the copper flotation concentrate of Sarcheshmeh, Kerman, Iran, were evaluated using shake flask leaching examinations. Experiments were carried out in the presence and absence of a mixed culture of moderately thermophile microorganisms at $50^{\circ} \mathrm{C}$. Chemical leaching experiments were performed in the absence and presence of $0.15 \mathrm{M}$ iron (ferric added medium, ferrous added medium and a mixture medium regulated at $420 \mathrm{mV}$, Pt. vs. $\mathrm{Ag} / \mathrm{AgCl}$ ). In addition, bioleaching experiments were carried out in the presence and absence of $0.1 \mathrm{M}$ iron (ferric and ferrous added mediua) at pulp density $10 \%(\mathrm{w} / \mathrm{v})$, inoculated bacteria $20 \%(\mathrm{v} / \mathrm{v})$, initial $\mathrm{pH} 1.6$, nutrient medium Norris and yeast extract addition $0.02 \%(\mathrm{w} / \mathrm{w})$. Abiotic leaching tests showed that the addition of iron at low solution redox potentials significantly increased the rate and extent of copper dissolution but when ferric iron was added, despite a higher initial rate of copper dissolution, leaching process stopped. Addition of both ferrous and ferric iron to the bioleaching medium levelled off the copper extraction and had an inhibitory effect which decreased the final redox potential. The monitoring of ferrous iron, ferric iron and copper extraction in leach solutions gave helpful results to understand the behaviour of iron cations during chemical and bacterial leaching processes.
\end{abstract}

Keywords: Ferric Iron; Ferrous Iron; Copper Concentrate; Leaching; Redox Potential

\section{Introduction}

During the last recent decades, copper leaching has been extensively studied as an alternative route to treat chalcopyrite concentrates.

The driving force in the leaching of metallic sulfides such as chalcopyrite, chalcocite and covellite is determined by the difference in the rest potential of the minerals present, and the redox potential of the leaching solution which mainly depends on the ferric to ferrous iron ratio as described by the Nernst equation (Equation (1)) [1].

$$
\mathrm{Eh}=\mathrm{Eh}^{\circ}+\frac{\mathrm{R} \cdot \mathrm{T}}{\mathrm{n} \cdot \mathrm{F}} \ln \frac{\left[\mathrm{Fe}^{3+}\right]}{\left[\mathrm{Fe}^{2+}\right]}
$$

where Eh is the solution redox potential in $\mathrm{mV}$ (with respect to hydrogen electrode), $\mathrm{Eh}^{\circ}$ is the standard equilibrium potential in $\mathrm{mV}, \mathrm{R}$ is the gas constant, $\mathrm{T}$ is temperature in $\mathrm{K}, \mathrm{n}$ is the charge number, $\mathrm{F}$ is Faraday's constant, $\left[\mathrm{Fe}^{3+}\right]$ and $\left[\mathrm{Fe}^{2+}\right]$ are the concentrations of the ferric and ferrous iron, respectively, in $\mathrm{mol} / \mathrm{l}$.

In bioleaching of copper concentrates, redox potential is one of the most important environmental parameters which affect biological and chemical subsystems. It in- creases by the activity of iron-oxidizing microorganisms. This increase is beneficial for the dissolution of most of the metallic sulfides such as chalcocite, covellite and pyrite, but, in the case of chalcopyrite, the leaching behavior is more complicated in which its dissolution rate is maximal at low redox potentials [2-11].

Furthermore, the growth and activity of iron-oxidizing microorganisms are affected by the concentrations of ferrous and ferric ions. Das et al. [12] reported that a low concentration of ferric iron enhances the oxygen uptaken by the acidophilic microorganisms, but at higher concentrations, ferric iron inhibits ferrous iron oxidation. In addition, increasing the ferrous iron to a certain critical concentration $(3 \mathrm{~g} / \mathrm{l})$ enhanced the oxidation rate while higher ferrous iron concentrations had an inhibitory effect [13].

Howard and Crundwell [14] found that increasing concentration of ferric iron in the range of 0.05 to $0.5 \mathrm{M}$ decreased the rate of chalcopyrite dissolution. Third et al. [6] also studied the effect of ferrous and ferric iron on the chemical and bacterial leaching of chalcopyrite at $37^{\circ} \mathrm{C}$ and found that high ferric concentration inhibits the bioleaching of chalcopyrite. They also confirmed the results obtained by Hiroyoshi et al. [2] and found that 
chemical leaching of chalcopyrite was increased 4-fold in the presence of $0.1 \mathrm{M}$ ferrous iron compared with $0.1 \mathrm{M}$ ferric iron. Cordoba et al. [8] studied the influence of ferric iron on chalcopyrite dissolution at low and high solution potentials and found that although ferric iron was responsible for the oxidation of chalcopyrite, ferrous iron had an important role in controlling the precipitation and nucleation of jarosite (Equation (2)).

$$
\begin{aligned}
& 3 \mathrm{Fe}^{3+}+\mathrm{X}^{+}+2 \mathrm{HSO}_{4}^{-}+6 \mathrm{H}_{2} \mathrm{O} \\
& \rightarrow \mathrm{XFe}_{3}\left(\mathrm{SO}_{4}\right)_{2}(\mathrm{OH})_{6}+8 \mathrm{H}^{+}
\end{aligned}
$$

The effect of ferric and ferrous iron on the extraction of copper and iron from flotation concentrates including both primary and secondary copper sulfides has not been well studied as yet. Hence, this research was done to investigate the effect of these cations on chemical and bacterial leaching of Sarcheshmeh copper concentrate in the presence and absence of mixed cultures of moderately thermophile microorganisms. The monitoring of the mentioned cations during the leaching processes is helpful to understand their behaviour during chemical and bacterial leaching processes.

\section{Materials and Methods}

\subsection{Minerals}

A flotation concentrate was obtained from Sarcheshmeh Copper Mine, Kerman, Iran. Mineralogical investigation on the representative sample was performed by optical microscopy using a Leica phase contrast microscope (DMLP). It showed that the concentrate contained $44.0 \%$ chalcopyrite $\left(\mathrm{CuFeS}_{2}\right), 24.0 \%$ pyrite $\left(\mathrm{FeS}_{2}\right), 6.9 \%$ covellite $(\mathrm{CuS}), 5.8 \%$ chalcocite $\left(\mathrm{CuS}_{2}\right), 13.6 \%$ non-metallic minerals and $4.8 \%$ copper oxide minerals. X-ray fluorescence (XRF) analysis showed that the concentrate included $27.5 \% \mathrm{Cu}, 23.0 \% \mathrm{Fe}, 14.8 \% \mathrm{~S}, 3.9 \% \mathrm{Si}$ and $1.0 \% \mathrm{Zn}$. The particle size distribution of the concentrate was determined by wet sieving and cyclosizer and showed that $80 \%$ was passing $76 \mu \mathrm{m}$.

\subsection{Microorganisms}

A mixed culture of moderately thermophilic iron- and sulfur oxidizing bacteria mainly containing Acidithiobacillus caldus, Solfobacillus and Thermosulfidooxidans obtained from Biohydrometallurgy Laboratory of Sarcheshmeh Copper Complex was used as inoculum in the bioleaching tests. Experiments were carried out at initial $\mathrm{pH} 1.5,50^{\circ} \mathrm{C}$ and Norris nutient medium [15] modified without iron with the following com-position: $0.4 \mathrm{~g} / \mathrm{l}$ $\left(\mathrm{NH}_{4}\right)_{2} \mathrm{SO}_{4}, 0.4 \mathrm{~g} / 1 \mathrm{~K}_{2} \mathrm{HPO}_{4}, 0.5 \mathrm{~g} / 1 \mathrm{MgSO}_{4} \cdot 7 \mathrm{H}_{2} \mathrm{O}$.

\subsection{Chemical Leaching Experiments}

To investigate the effect of ferric and ferrous iron as well as redox potential on the chemical leaching of Sarcheshmeh copper concentrate, four slurries with different initial redox potentials were prepared (Table 1) in 500 ml-Erlenmeyer flasks containing $200 \mathrm{ml}$ suspension. These shake flask experiments were carried out in the following conditions: initial iron concentration $0.15 \mathrm{M}$ (except control test R1), pulp density 1\% (w/v), initial $\mathrm{pH} 1.8$, stirring rate $150 \mathrm{rpm}$ and $50^{\circ} \mathrm{C}$. To prevent microbial growth, the medium was sterilized with $2 \%(\mathrm{v} / \mathrm{v})$ bactericide $(2 \%(\mathrm{w} / \mathrm{w})$ thymol in ethanol) added. The solution of test $\mathrm{R} 4$ was prepared to obtain the redox potential of $420 \mathrm{mV}$ (Pt vs. $\mathrm{Ag} / \mathrm{AgCl}$ ) by mixing ferric and ferrous sulfates in which total iron concentration was maintained at $0.15 \mathrm{M}$. The low solid to liquid ratio was chosen to avoid sharp changes of the redox potential of the medium during the first instant of leaching.

\subsection{Bacterial Leaching Experiments}

In order to determine the influence of ferrous and ferric iron addition on the bioleaching of the copper concentrate, shake flasks experiments were carried out in the presence and absence of $0.1 \mathrm{M}$ of the mentioned cations. These experiments were carried out in 500 ml-Erlenmeyer flasks containing $200 \mathrm{ml}$ of suspension of the concentrate at a pulp density of $10 \%(\mathrm{w} / \mathrm{v})$ in the modified Norris's medium supplemented with $0.02 \%(\mathrm{w} / \mathrm{v})$ yeast extract and having an initial $\mathrm{pH}$ of 1.5. Each flask was inoculated with a bacterial suspension $(20 \% \mathrm{v} / \mathrm{v})$ and then incubated at $50^{\circ} \mathrm{C}$ and $150 \mathrm{rpm}$ on a rotary shaker. To inoculate bacteria to a fresh medium, the bacterial solution was added to an Erlenmeyer flask containing the required fresh nutrient solution (at the desired $\mathrm{pH}$ ). Then, the desired amount of concentrate and ferric and/or ferrous iron when necessary, was added to the flask. After mixing the resulting slurry, the $\mathrm{pH}$ was regulated and the redox potential was recorded. These biotic experiments were inoculated with an active culture (as solution) with the cell density of about $2.7 \times 10^{8}$ cells $/ \mathrm{ml}$, which had been previously adapted to a $10 \%$ pulp density of the concentrate.

Evaporation loss was measured by weighting flaks and then was compensated by adding distilled water to the slurry before sampling.

Table 1. Initial concentrations of ferrous and ferric ions and the values of initial redox potential in the solutions.

\begin{tabular}{ccccc}
\hline Test No. & R1 & R2 & R3 & R4 \\
\hline $\begin{array}{c}\text { Iron } \\
\text { Concentration }\end{array}$ & 0 & $\begin{array}{c}0.15 \mathrm{M} \\
\text { Fe (II) }\end{array}$ & $\begin{array}{c}0.15 \mathrm{M} \\
\text { Fe (III) }\end{array}$ & $\begin{array}{c}\text { Fe total } \\
\begin{array}{c}\text { Initial redox } \\
\text { potential (mV, vs. } \\
\text { Ag/AgCl) }\end{array}\end{array}$ \\
\hline
\end{tabular}




\subsection{Analyses}

The concentration of total iron and copper in the leach solutions was determined by atomic absorption spectroscopy (AAS) (model: Varian 240). After each test, the solid residue was filtered, rinsed with distilled water, left to air dry and sent for analyzing by AAS. The concentration of ferrous iron in the solution was determined by titration with potassium dichromate $0.01 \mathrm{~N}$ using sodium diphenylamine sulfonate as indicator. The difference in the concentration of total iron and ferrous iron was considered as the concentration of ferric iron in the solution. The $\mathrm{pH}$ and redox potential values in the leach solutions were measured with a pH meter (model: Jenway 3540) and a $\mathrm{Pt}$ electrode in reference to an $\mathrm{Ag} / \mathrm{AgCl}$ electrode $\left(+207 \mathrm{mV}\right.$ vs. SHE at $\left.25^{\circ} \mathrm{C}\right)$, respectively. For all experiments, analytical grade reagents and distilled water were used.

\section{Results and Discussion}

\subsection{Effect of Ferric and Ferrous Iron on Chemical Leaching}

Variation of redox potential with time is shown in Figure 1. It can be seen that the redox potential in the ferrous medium rose from 345 to $449 \mathrm{mV}$ over 8 days while in the ferric medium its value decreased from 535 to 472 $\mathrm{mV}$ in the same period of time. On the other hand, redox potential in both media regulated at $420 \mathrm{mV}$ and the sterile medium did not change remarkably during the leaching experiments. Variation of redox potential shows that in the ferrous medium, ferric ions were produced during leaching of the concentrate, while in the ferric medium, ferrous ions were entered into the solution. This result was confirmed by analyzing the ferrous and total iron in the final solutions (Figure 2). The increase of the redox potential in the ferrous medium was probably related to the oxidation of ferrous iron by oxygen present in the solution which can surpass ferric reduction as a result of low solid content. It may also be as a consequence of the activity of bacteria present in the concentrate which had not been killed by the bactericide. While, the decrease of redox potential in the ferric medium was mainly attributed as a result of reducing ferric iron to ferrous iron on the surface of the minerals (dissolution process). The redox potential in the control test remained around 326 to $360 \mathrm{mV}$. This low increase may be as a result of natural ferrous oxidation at the relatively high temperature. Figure 3 shows that the values of solution $\mathrm{pH}$ at the end of experiments remained at low levels (from 1.17 to 1.52) in which after the initial two days, decreasing the $\mathrm{pH}$ by $\mathrm{H}_{2} \mathrm{SO}_{4}$ was not necessary. The minimum and maximum $\mathrm{pH}$ values were related to ferric (without any acid addition) and control media (acid was added up to day 4), respectively. $\mathrm{pH}$ decrease could be related to the forma- tion of $\mathrm{H}_{2} \mathrm{~S}$ as a result of acidic leaching of copper sulfides according to Equations (3) to (5), which can then be converted to acid according to Equations (6) to (8).

$$
\begin{gathered}
\mathrm{Cu}_{2} \mathrm{~S}+2 \mathrm{H}^{+} \rightarrow \mathrm{Cu}^{2+}+\mathrm{Cu}^{\circ}+\mathrm{H}_{2} \mathrm{~S} \\
\mathrm{CuS}+2 \mathrm{H}^{+} \rightarrow \mathrm{Cu}^{2+}+\mathrm{H}_{2} \mathrm{~S} \\
\mathrm{CuFeS}_{2}+4 \mathrm{H}^{+} \rightarrow \mathrm{Cu}^{2+}+\mathrm{Fe}^{2+} 2 \mathrm{H}_{2} \mathrm{~S}
\end{gathered}
$$

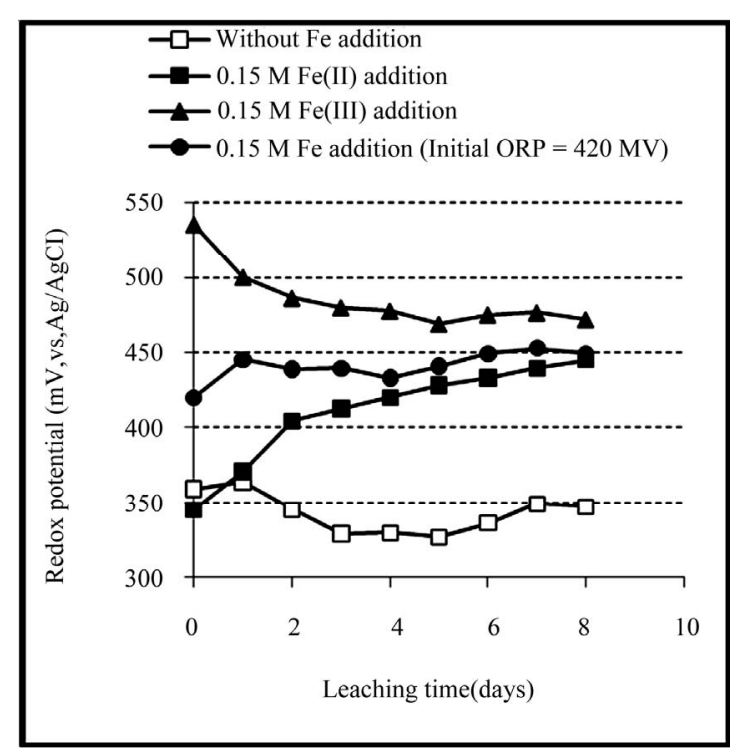

Figure 1. Variation of redox potential during the chemical leaching of the copper concentrate at $0.15 \mathrm{M}$ iron addition (except the control test), pulp density $1 \%(w / v), 50^{\circ} \mathrm{C}$, nutrient medium Norris and initial pH 1.8 .

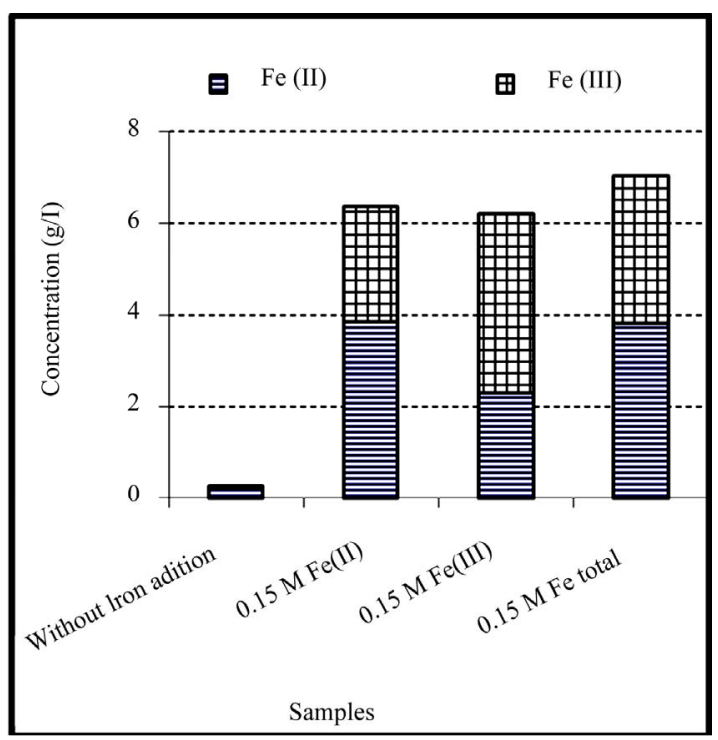

Figure 2. Concentration of ferrous and ferric iron in the final solutions of chemical leaching of the copper concentrate at $0.15 \mathrm{M}$ iron addition (except the control test), pulp density $1 \%(\mathrm{w} / \mathrm{v}), 50^{\circ} \mathrm{C}$, nutrient medium Norris and initial pH 1.8. 


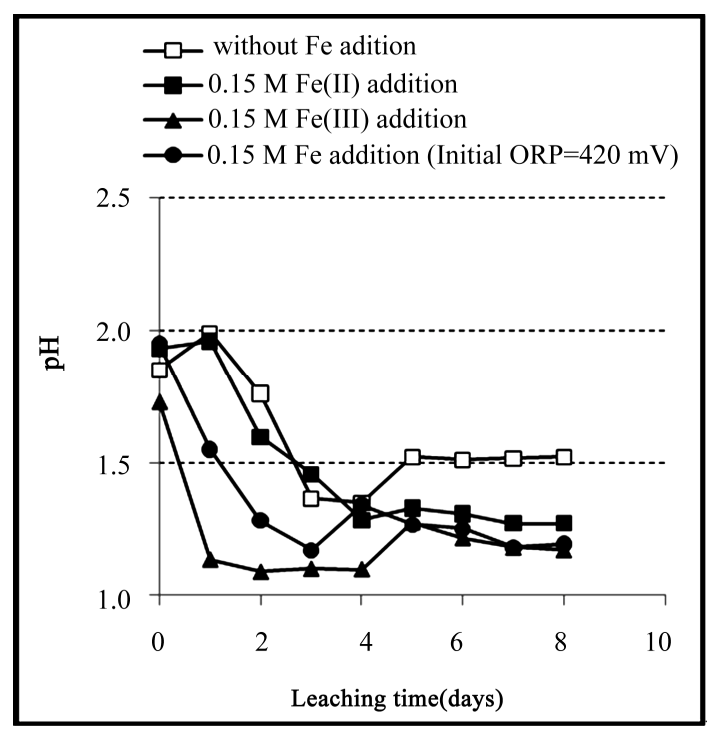

Figure 3. Variation of $\mathrm{pH}$ during the chemical leaching of the copper concentrate at $0.15 \mathrm{M}$ iron addition (except the control test), pulp density $1 \%(\mathrm{w} / \mathrm{v}), 50^{\circ} \mathrm{C}$, nutrient medium Norris and initial pH 1.8.

$$
\begin{gathered}
\mathrm{H}_{2} \mathrm{~S}+\mathrm{Cu}^{2+} \rightarrow \mathrm{CuS}+2 \mathrm{H}^{+} \\
\mathrm{H}_{2} \mathrm{~S}+\frac{1}{2} \mathrm{O}_{2} \rightarrow \mathrm{S}^{\circ}+\mathrm{H}_{2} \mathrm{O} \\
\mathrm{H}_{2} \mathrm{~S}+2 \mathrm{Fe}^{3+} \rightarrow \mathrm{S}^{\circ}+2 \mathrm{Fe}^{2+}+2 \mathrm{H}^{+}
\end{gathered}
$$

Figure 4 presents the results of copper extraction during leaching of the concentrate. It can be seen that the initial rates of copper extraction in the media with iron addition (especially ferric medium and the medium regulated at $420 \mathrm{mV}$ ) were significantly higher than those in the test with no iron addition. However, the final extraction in the test regulated at redox potential of $420 \mathrm{mV}$ and the test with ferrous addition are maximal. The initial increases were followed by a parabolic behaviour attributed to the chalcopyrite passivation. The high initial rates of copper dissolution were mainly related to the dissolution of copper oxides and secondary copper sulfides. The final copper recoveries were $21.9 \%, 39.6 \%, 44.6 \%$ and $46.2 \%$ for control test, ferric added medium, ferrous added medium and the medium with the initial redox potential of $420 \mathrm{mV}$, respectively. This result is in agreement with those obtained by Hiroyoshi et al. [2] and Third et al. [6] who reported that ferrous iron is more effective than ferric iron to dissolve chalcopyrite. Higher copper extraction rate in the first day of ferric added medium was related to the higher efficiency of chalcocite and covellite in ferric media.

On the other hand, as shown in Figure 5, in the experiments that iron has been added, the iron concentra tion in the solution was reduced during the process. This

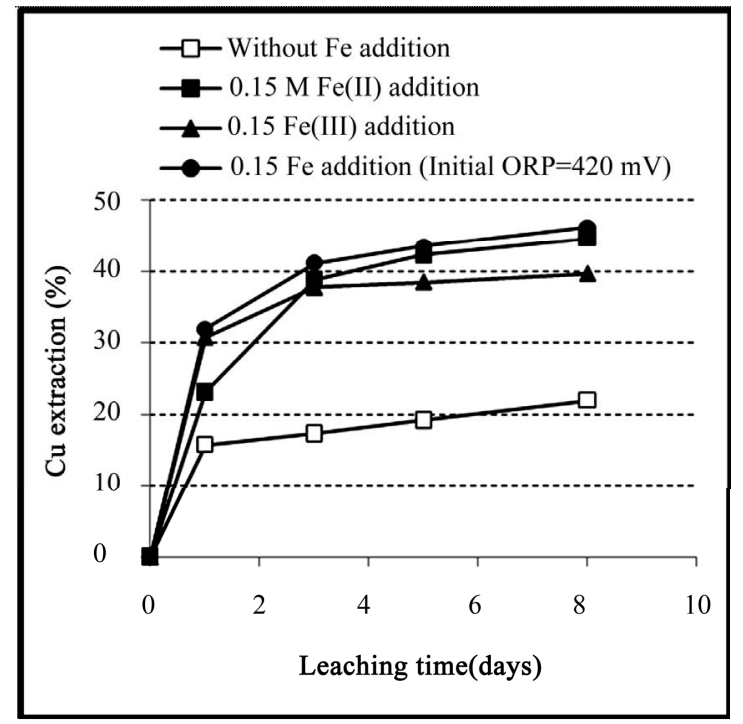

Figure 4. Extraction of copper during the chemical leaching of the copper concentrate at $0.15 \mathrm{M}$ iron addition (except the control test), pulp density $1 \%(\mathrm{w} / \mathrm{v}), 50^{\circ} \mathrm{C}$, nutrient medium Norris and initial pH 1.8 .

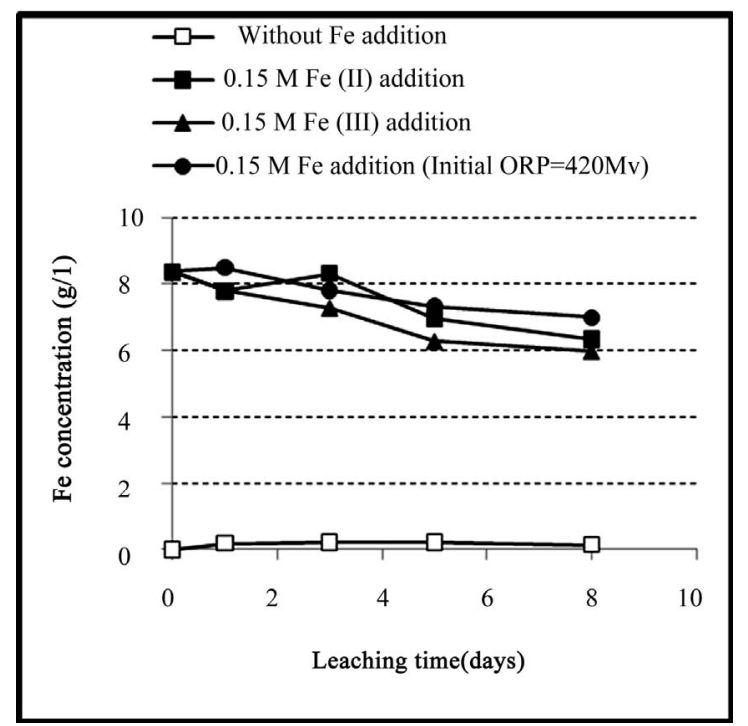

Figure 5. Variation of iron concentration in solution during the chemical leaching of the copper concentrate at $0.15 \mathrm{M}$ iron addition (except the control test), pulp density $1 \%$ (w/v), $50^{\circ} \mathrm{C}$, nutrient medium Norris and initial $\mathrm{pH} 1.8$.

decrease was occurred in both ferrous and ferric media especially in the latter medium. The reason for this decrease was ascribed to the precipitation of a part of iron present in the solution as iron-hydroxy precipitates such as jarosite in the ferric medium and goethite and/or hematite in the ferrous medium. These precipitates were considered as one of the most probable causes to slow down the leaching rate. 


\subsection{Effect of Ferric and Ferrous Iron on Bacterial Leaching}

Figures 6 and 7 present the variation of redox potential and $\mathrm{pH}$ during the bioleaching experiments. Figure 6 shows that the addition of ferric iron caused a high initial redox potential $(490 \mathrm{mV})$ but it did not remain constant in the following days. At the first day of the leaching process, the redox potential decreased from 490 to 370 $\mathrm{mV}$, after that, it began to increase, but its final values remained lower than those in the test with no iron addition. This indicates that the high concentration of ferric iron reduced the ability of bacteria to oxidize ferrous iron. This inhibition effect had previously been reported by Lin et al. [16] in bioleaching of pyrite using At. ferrooxidans and Leptospirillum ferriphilum bacteria, and the research conducted by Nyavor et al. [17] who reported that the high concentration of ferric iron competitively inhibits ferrous iron oxidation by At. ferrooxidans.

For the case of ferrous addition, the redox potential began to increase rapidly from $319 \mathrm{mV}$ to about $490 \mathrm{mV}$ after 5 days (Figure 6), this was then followed by a slight increase to the maximum redox potential of 515 $\mathrm{mV}$ over the next 11 days. This result shows that the high level of initial ferrous iron had also an inhibitory effect on the yield of bacterial oxidation of ferrous iron. However, this inverse effect may also be related to the high concentration of ferric iron ( $4.12 \mathrm{~g} / 1$ in day 6$)$ which had been produced by the bacterial oxidation of added ferrous iron. As a result, both solutions which iron had been added to them would have a similar composition after several days. Lower values of redox potential were also attributed to the formation of ferric hydroxides such as jarosite (Equation (1)), causing a decrease in ferric iron in the solution, which in turn led to a decrease in the value of redox potential. Essential nutrients needed for the activity and growth of bacteria were also precipitated with iron hydroxides which hamper the activity and growth of bacteria. These results were in agreement with the research conducted by Kawabe et al. [18] who reported that the complete inhibitory effect of ferric iron on bacterial growth was achieved at a high level of ferric iron $(>0.3 \mathrm{M})$.

The variations of $\mathrm{pH}$ during bioleaching experiments were shown in Figure 7. It can be seen that, for the experiment with no iron addition, after a transient increase, $\mathrm{pH}$ value decreased gradually to about 1.5 (after 9 days) mainly due to the activity of sulfur-oxidizing bacteria to produce acid (Equation (9)). After this time, $\mathrm{pH}$ remained constant around 1.5 over the next 7 days.

$$
\mathrm{S}^{\circ}+\mathrm{H}_{2} \mathrm{O}+\frac{3}{2} \mathrm{O}_{2} \rightarrow \mathrm{H}_{2} \mathrm{SO}_{4}
$$

For the experiments with iron addition, a similar pattern was observed in which after a transient increase in the first few days, $\mathrm{pH}$ was gradually decreased to about

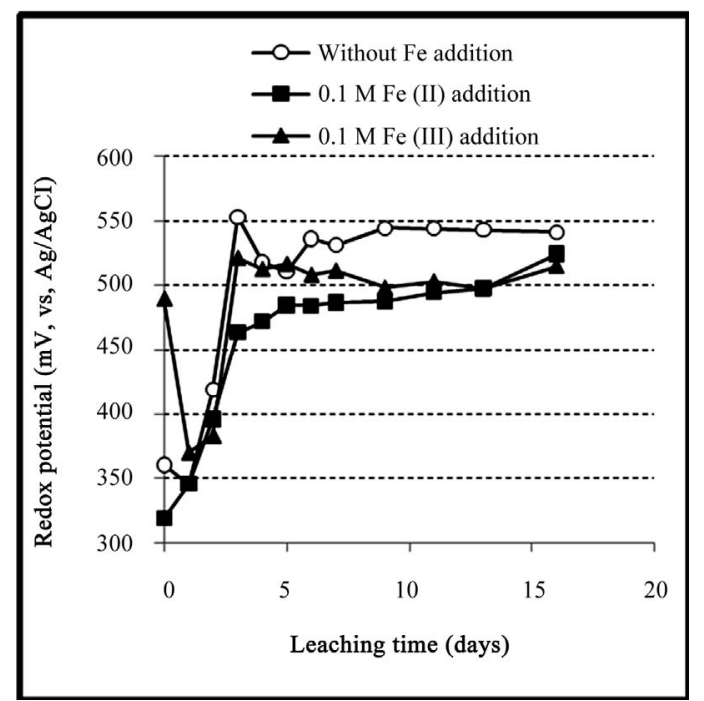

Figure 6. Variation of redox potential during the bioleaching of the copper concentrate with and without $0.1 \mathrm{M}$ iron addition at pulp density $10 \%(\mathrm{w} / \mathrm{v}), 50^{\circ} \mathrm{C}$, nutrient medium Norris and initial pH 1.6.

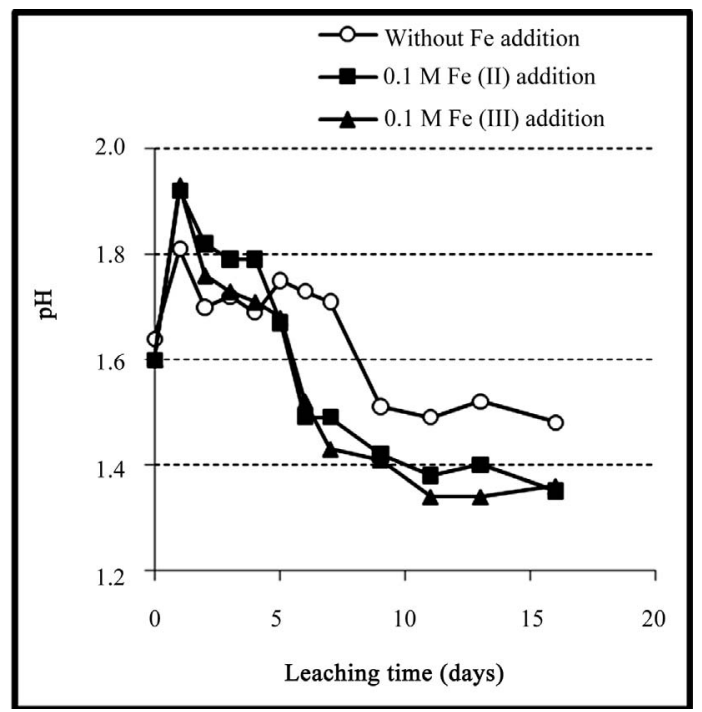

Figure 7. Variation of $\mathrm{pH}$ during the bioleaching of the copper concentrate with and without $0.1 \mathrm{M}$ iron addition at pulp density $10 \%, 50^{\circ} \mathrm{C}$, nutrient medium Norris and initial pH 1.6.

1.4 after 9 days. The lower $\mathrm{pH}$ value in the experiments with iron addition was attributed to the formation of jarosite which is an acid producing reaction (Equation (2)).

Figures 8 and 9 show the results of copper and iron extraction during the bioleaching experiments. Figure 8 shows that the addition of iron into the solution increased the initial rates of copper extraction $(\sim 14 \%$ /day in the iron added medium versus $10.5 \%$ /day in the non added iron medium) which were followed by leveling off the extraction curves. The flat regions in the last 10 days of iron added cultures were attributed to the passivation of 
chalcopyrite surface. It can be seen that the yield of copper extraction in the ferric medium $(36.7 \%)$ was significantly lower than that obtained in the experiment with no iron addition (43.1\%) and one that ferrous iron was added $(41.5 \%)$. Copper extraction rates in the last 10 days were $0.02 \%, 0.18 \%$ and $1.1 \%$ day in the ferric, ferrous and non added iron media, respectively.

Figure 9 shows that in the ferric added medium the amount of dissolved iron was lower than the amount of

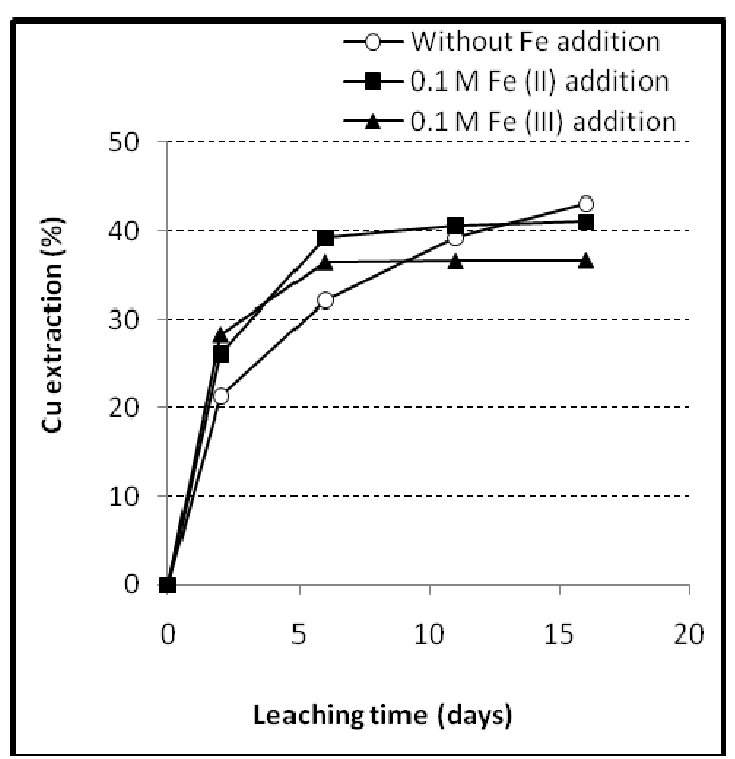

Figure 8. Extraction of copper during the bioleaching of the copper concentrate with and without $0.1 \mathrm{M}$ iron addition at pulp density $10 \%(\mathrm{w} / \mathrm{v}), 50^{\circ} \mathrm{C}$, nutrient medium Norris and initial pH 1.6.

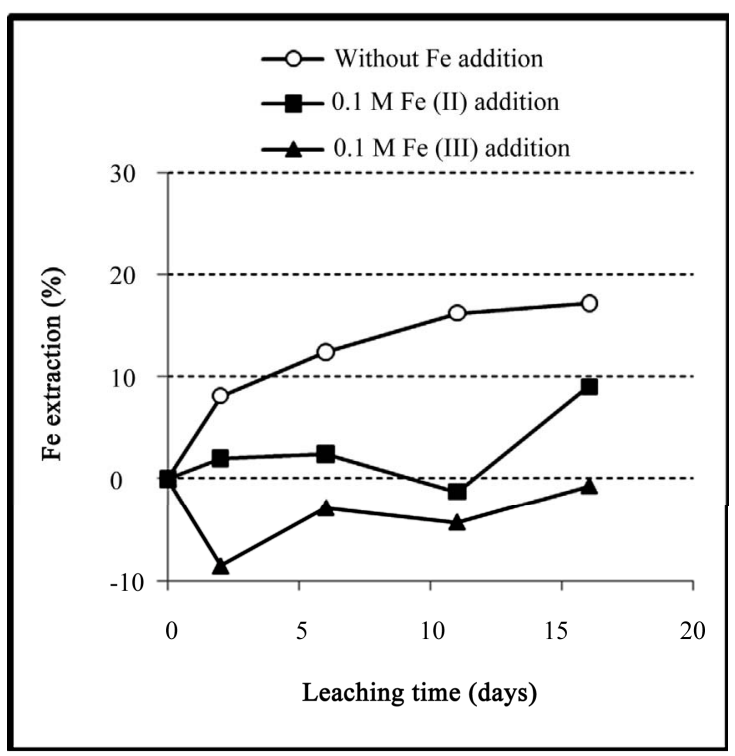

Figure 9. Extraction of iron during the bioleaching of the copper concentrate with and without $0.1 \mathrm{M}$ iron addition at pulp density of $10 \%(w / v), 50^{\circ} \mathrm{C}$, nutrient medium Norris and initial pH 1.6. precipitated iron (negative extraction). The drop of iron extraction in the 2 nd day of ferric added medium and $11^{\text {th }}$ day of ferrous added medium were probably due to the precipitation of jarosite. The final iron extraction in the experiment with no iron addition reached $17.2 \%$.

To explain the role of ferrous iron in chalcopyrite leaching two models have been proposed. The first model expressed that ferrous iron acts as a catalyst for converting chalcopyrite to chalcocite as a more soluble mineral (Hiroyoshi et al., [2]) and the second one related that the dissolved oxygen converted ferrous to ferric iron at the chalcopyrite surface and the reaction proceeds as expected [19].

\section{Conclusions}

The following results were obtained from chemical and bacterial leaching experiments for Sarcheshmeh chalcopyrite concentrate:

In the abiotic leaching tests, it was found that the addition of iron at low solution redox potentials (around 420 $\mathrm{mV}$ ) significantly increased the rate and extent of copper dissolution but when only ferric iron was added, despite a higher initial rate of copper dissolution, leaching process stopped after several days. Decreasing the concentration of dissolved iron was occurred in both ferrous and ferric media especially in the latter medium. The reason for this decrease could be related to the removal of a part of iron present in the solution as iron-hydroxy precipitates. It can be jarosite in the ferric medium and goethite and/or hematite in the ferrous medium.

Addition of both ferrous and ferric iron to the bioleaching medium leveled off the copper extraction and had an inhibitory effect which decreased the final redox potential. It indicates the lower ability of bacteria to oxidize ferrous iron in the presence of these cations.

\section{Acknowledgements}

The support of the National Iranian Copper Industry Company for providing the materials is gratefully acknowledged.

\section{REFERENCES}

[1] G. Rossi, "Biohydrometallurgy," McGraw Hill, Hamburg, 1990.

[2] N. Hiroyoshi, M. Hirota, T. Hirajima and M. Tsunekawa, "A Case of Ferrous Sulfate Addition Enhancing Chalcopyrite Leaching," Hydrometallurgy, Vol. 47, No. 1, 1997, pp. 37-45. doi:10.1016/S0304-386X(97)00032-7

[3] N. Hiroyoshi, H. Miki, T. Hirajima and M. Tsunekawa, "Enhancement of Chalcopyrite Leaching by Ferrous Ions in Acidic Ferric Sulfate Solutions," Hydrometallurgy, Vol. 60, No. 3, 2001, pp. 185-197. doi:10.1016/S0304-386X(00)00155-9 
[4] N. Hiroyoshi, H. Kitagawa and M. Tsunekawa, "Effect of Solution Composition on the Optimum Redox Potential for Chalcopyrite Leaching in Sulfuric Acid Solutions," Hydrometallurgy, Vol. 91, No. 1-4, 2008, pp. 144-149. doi:10.1016/j.hydromet.2007.12.005

[5] A. Pinches, P. J. Myburgh and C. Merwe, "Process for the Rapid Leaching of Chalcopyrite in the Absence of Catalysis," US patent No. 6277341 B1, 2001.

[6] K. A. Third, R. Cord-Ruwisch and H. R. Watling, "Control of the Redox Potential by Oxygen Limitation Improves Bacterial Leaching of Chalcopyrite," Biotechnology and Bioengineering, Vol. 78, No. 4, 2002, pp. 433441. doi:10.1002/bit.10184

[7] A. Sandström, A. Shchukarev and J. Paul, "XPS Characterisation of Chalcopyrite Chemically and Bio-Leached at High and Low Redox Potential," Minerals Engineering, Vol. 18, No. 5, 2005, pp. 505-515. doi:10.1016/j.mineng.2004.08.004

[8] E. M. Cordoba, J. A. Munoz, M. L. Blázquez, F. González and A. Ballester, "Leaching of Chalcopyrite with Ferric Ion. Part IV: The Role of Redox Potential in the Presence of Mesophilic and Thermophilic Bacteria," $\mathrm{Hy}$ drometallurgy, Vol. 93, No. 3-4, 2008. pp. 106-115. doi:10.1016/j.hydromet.2007.11.005

[9] M. Gericke, Y. Govender and A. Pinches, "Tank Bioleaching of Low-Grade Chalcopyrite Concentrates Using Redox Control," Hydrometallurgy, Vol. 104, No. 3-4, 2010, pp. 414-419. doi:10.1016/j.hydromet.2010.02.024

[10] A. Ahmadi, M. Schaffie, Z. Manafi and M. Ranjbar, "Electrochemical Bioleaching of High Grade Chalcopyrite Flotation Concentrate in a Stirred Tank Reactor," Hydrometallurgy, Vol. 104, No. 1, 2010, pp. 99-105. doi:10.1016/j.hydromet.2010.05.001

[11] A. Ahmadi, M. Schaffie, J. Petersen, A. Schippers and M. Ranjbar, "Conventional and Electrochemical Bioleaching of Chalcopyrite Concentrates by Moderately Thermophile Bacteria at High Pulp Density," Hydrometallurgy, Vol. 106, No. 1-2, 2011, pp. 84-92. doi:10.1016/j.hydromet.2010.12.007

[12] T. Das, S. Ayyappan and G. R. Chaudhury, "Factors Affecting Bioleaching Kinetics of Sulfide Ores Using Acidophilic Micro-Organisms," BioMetals, Vol. 12, No. 1, 1999, pp. 1-10. doi:10.1023/A:1009228210654

[13] J. L. Barron and D. R. Lueking, "Growth and Maintenance of Thiobacillus ferrooxidans Cells," Applied and Environmental Microbiology, Vol. 56, 1990, pp. 28012806.

[14] D. Howard and F. K. Crundwell, "A Kinetic Study of the Leaching of Chalcopyrite with Sulfolobus Metallicus," Biohydrometallurgy and the Environment toward the Mining of the 21st Century, 1999, pp. 209-217.

[15] P. R. Norris and D. W. Barr, "Growth and Iron Oxidation by Acidophilic Moderate Thermophiles," FEMS Microbiology Letters, Vol. 28, No. 3, 1985, pp. 221-224. doi:10.1111/j.1574-6968.1985.tb00795.X

[16] L. Zhang, G.-Z. Qiu, Y.-H. Hu, X.-J. Sun, J.-H. Li and G.-H. Gu, "Bioleaching of Pyrite by A. ferrooxidans and L. ferriphilum," Transactions of Nonferrous Metals Society of China, Vol. 18, No. 6, 2008, pp. 1415-1420. doi:10.1016/S1003-6326(09)60018-2

[17] K. Nyavor, N. O. Egiebor and P. M. Fedorak, "The Effect of Ferric Ion on the Rate of Ferrous Oxidation by Thiobacillus ferrooxidans," Applied Microbiology and Biotechnology, Vol. 45, No. 5, 1996, pp. 688-691. doi:10.1007/s002530050749

[18] Y. Kawabe, C. Inoue, K. Suto and T. Chida, "Inhibitory Effect of High Concentrations of Ferric Ions on the Activity of Acidithiobacillus ferrooxidans," Journal of Bioscience and Bioengineering, Vol. 96, No. 4, 2003, pp. 375-379.

[19] C. Klauber, "A Critical Review of the Surface Chemistry of Acidic Ferric Sulfate Dissolution of Chalcopyrite with Regards to Hindered Dissolution," International Journal of Mineral Processing, Vol. 86, No. 1-4, 2008, pp. 1-17. doi:10.1016/j.minpro.2007.09.003 